\title{
KAMUS ISTILAH ILMU KOMPUTER DENGAN ALGORITMA BOYER MOORE BERBASIS WEB
}

\author{
Dwipa Handayani ${ }^{1}$, Abrar Hiswara ${ }^{2}$ \\ ${ }^{12}$ Fakultas Teknik Informatika, Universitas Bhayangkara Jakarta Raya \\ Jl. Raya Perjuangan, Marga Mulya, Bekasi Utara 17123 \\ Telp. (021) 88955882 Fax. (021) 88955882-3 \\ e-mail : dwipa.handayani@dsn.ubharajaya.ac.id, abrar@dsn.ubharajaya.ac.id
}

\begin{abstract}
A dictionary is a reference book that contains words and phrases that are usually arranged in alphabetical order along with an explanation of their meaning, usage and translation and function to help recognize new terms. The field of computer science certainly has specific terms related to computers, so it is needed a dictionary of computer terms, currently the existing dictionary is still conventional in its use ineffective and inefficient. The design and manufacture of applications using algorithms by performing a sequence of logical steps in solving problems that are arranged systematically. Algorithms for searching are now growing day by day. Boyer Moore algorithm is one of the search algorithms that is considered to have the best results, namely the algorithm that moves matching strings from right to left. With this web-based dictionary the user is expected to be able to get information quickly, without any limitations on space and time.
\end{abstract}

Keywords: Boyer Moore's Algorithm, Computer Science, Glossary of Terms, Web.

\begin{abstract}
ABSTRAK
Kamus adalah buku acuan yang memuat kata dan ungkapan yang biasanya disusun menurut abjad berikut keterangan maknanya, pemakaiannya dan terjemahannya serta berfungsi untuk membantu mengenal istilah - istilah baru. Bidang ilmu komputer pasti memiliki istilah khusus yang berhubungan dengan komputer, maka dibutuhkan kamus istilah komputer, saat ini kamus yang ada masih bersifat konvensional yang dalam penggunaannya tidak efektif dan efisien. Perancangan dan pembuatan aplikasi menggunakan algoritma dengan melakukan urutan langkah-langkah logis pada penyelesaian masalah yang disusun secara sistematis. Algoritma untuk pencarian pun saat ini sudah semakin berkembang dari hari ke hari. Algoritma boyer moore merupakan salah satu algoritma pencarian yang dianggap memiliki hasil paling baik yaitu algoritma yang bergerak mencocokkan string dari arah kanan ke kiri. Dengan kamus istilah berbasis web ini diharapkan pemakai bisa mendapatkan infomasi dengan cepat, tanpa adanya batasan ruang dan waktu.
\end{abstract}

Kata Kunci : Algoritma Boyer Moore, Ilmu Komputer, Kamus Istilah, Web. 


\section{Pendahuluan}

Di dalam dunia pendidikan atau setiap bidang pasti memiliki istilah khusus yang berhubungan dengan bidang tersebut, begitu juga untuk ilmu komputer. Istilah ilmu komputer merupakan kata atau gabungan kata yang mengungkapkan suatu makna, konsep, proses, dan keadaan yang berhubungan dengan ilmu komputer. Untuk mendapatkan informasi istilah-istilah ilmu komputer maka dibutuhkan kamus istilah ilmu komputer. Pada awalnya kamus istilah ilmu komputer dibuat pada buku cetak konvensional. Penggunaan buku cetak konvensional tidak praktis bagi pemakai.

Banyak sekali buku kamus istilah komputer yang beredar tetapi buku tersebut justru menyulitkan belum lagi proses mencari informasinya cukup lama karena pengguna harus menelusuri lembar demi lembar halaman buku yang dimiliki untuk mencari arti dari istilah komputer secara manual. Namun tidak banyak dari kita yang memiliki koleksi buku yang lengkap, selain harganya yang relatif mahal, biasanya ukuran buku cukup besar dan tebal sehingga sulit untuk dibawa kemana-mana. Kelemahan yang lainnya adalah buku tersebut tidak dapat mengikuti perkembangan ilmu komputer pada saat ini. Muncul berbagai aplikasi kamus berbasis mobile ataupun desktop untuk memudahkan pengguna dalam menggunakannya namun tetap masih ada kelemahan pada aplikasiaplikasi seperti dalam melakukan proses pencariaan suatu istilah.

Terbukti dari penjualan buku cetak yang menurun di salah satu perusahaan penjual buku terbesar di Indonesia, dari 4 tahun terakhir yaitu di Gramedia. Dapat dilihat dalam bentuk grafik diagram .

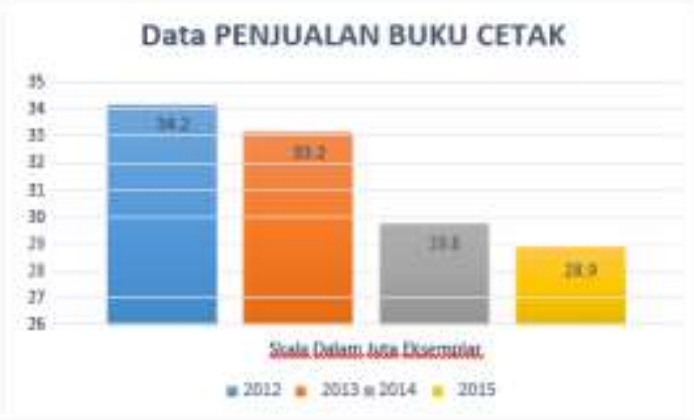

Gambar 1. Diagram Penjualan Buku Di Gramedia

Sumber : https://tirto.id/melawangoliat-perdagangan-buku-835

Data yang terdapat di grafik Gambar 1 diambil dari sumber di internet yang telah dirangkum dari informasi yang didapatkan oleh penulis dalam bentuk tabel 1 berikut ini :

Tabel 1. Data Penjualan Buku Cetak Di Gramedia

\begin{tabular}{|l|l|l|l|}
\hline No & Tahun & Jumlah Terjual & Status \\
\hline 1 & 2012 & 34.2 juta eksemplar & Stabil \\
\hline 2 & 2013 & 33.2 juta eksemplar & Menurun \\
\hline 3 & 2014 & 29.8 juta eksemplar & Menurun \\
\hline 4 & 2015 & 28.9 juta eksemplar & Menurun \\
\hline
\end{tabular}


Proses pencarian dalam suatu aplikasi kamus istilah ilmu komputer sangat penting, namun terkadang proses pencarian itu lambat. Untuk mempercepat dan mempermudah suatu proses pencarian, dibutuhkan suatu algoritma yang dapat memaksimalkan proses pencarian tersebut. Algoritma Boyer Moore menggunakan metode pencocokan string dari kanan ke kiri yaitu men scan karakter pattern dari kanan ke kiri dimulai dari karakter paling kanan.

Masalah dapat berupa apa saja, dengan catatan untuk setiap masalah ada syarat kondisi awal yang harus dipenuhi sebelum menjalankan algoritma. Algoritma untuk pencarian pun sudah semakin berkembang dari hari ke hari. Algoritma pencarian yang dianggap memiliki hasil paling baik dalam praktiknya, yaitu algoritma yang bergerak mencocokkan string dari arah kanan ke kiri. Algoritma Boyer-Moore merupakan salah satu contoh algoritma yang menggunakan arah dari kanan ke kiri.

\section{Metode Penelitian}

Dalam penyusunan penelitian ini penulis membutuhkan objek penelitian, dalam kasus ini objek penelitian yang penulis pilih adalah SMK Bina Siswa Utama yang berlokasi di Jl. Aster Raya No.15, Perumahan Harapan Baru, Bekasi Barat. SMK Bina Siswa utama merupakan salah satu sekolah yang berdiri di bawah Yayasan Bina Siswa Utama didirikan pada 12 Januari 1991.

SMK Bina Siswa Utama Memiliki 6 ( enam ) macam Program Kompetensi yang masing - masing telah terakreditasi. Adapun ke - 6 program keahlian tersebut adalah :

1. Teknik Kendaraan Ringan

2. Teknik Sepeda Motor

3. Akuntasi

4. Administrasi Perkantoran

5. Teknik Komputer dan Jaringan

6. Multimedia

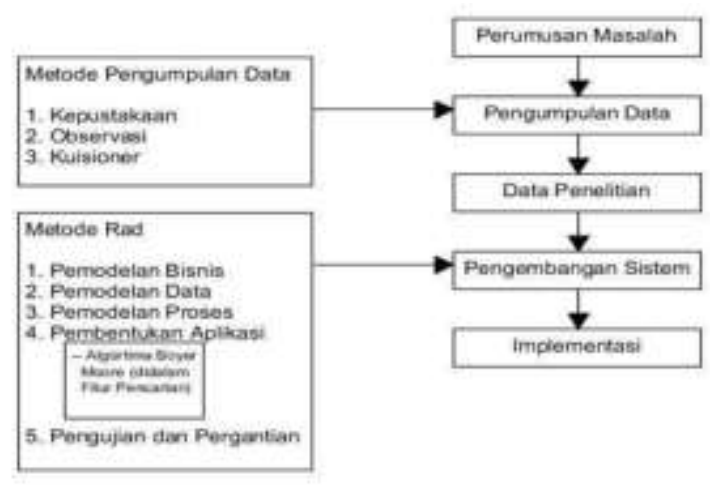

Gambar 2. Kerangka Penelitian

\subsection{Analisa Sistem}

Analisis sistem merupakan penguraian dari suatu sistem yang utuh kedalam bagian-bagian komponennya dengan maksud untuk mengindentifikasikan yang diharapkan sehingga dapat diusulkan perbaikan-perbaikannya. 
Dalam kegiatan pengembangan aplikasi kamus istilah ilmu computer berbasis web di SMK Bina Siswa Utama Bekasi sebagai pokok pembahasaan dalam laporan penulisan ini, yaitu aplikasi ini dapat berperan sangat penting pada saat kegiatan belajar mengajar di kelas terutama di jurusan Teknik Komputer Jaringan di sekolah ini.

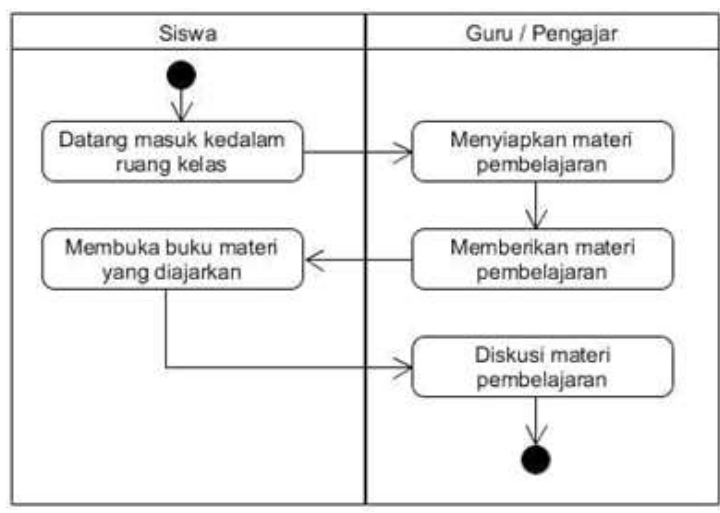

Gambar 3. Activity Diagram Kegiatan Belajar Mengajar Yang Berjalan

\subsection{Use Case Diagram}

Merupakan sebuah teknik yang digunakan dalam pengembangan sebuah software atau sistem informasi untuk menangkap kebutuhan fungsional dari sistem yang bersangkutan, use case menjelaskan interaksi yang terjadi antara aktor. 'inisiator' dari interaksi sistem itu sendiri dengan sistem yang ada. Dibawah ini ada use case dari aplikasi kamus istilah ilmu computer berbasis web.

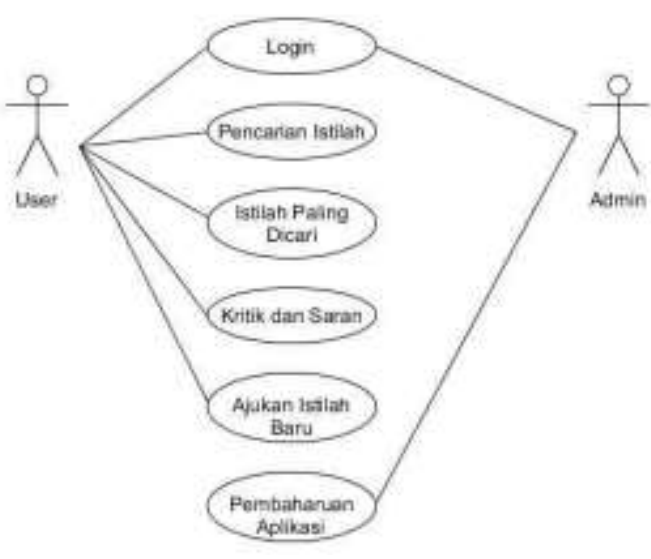

Gambar 4. Use Case Kamus Istilah Ilmu Komputer Berbasis Web

\subsection{Activity Diagram}

2.3.1 Activity Diagram Halaman Utama

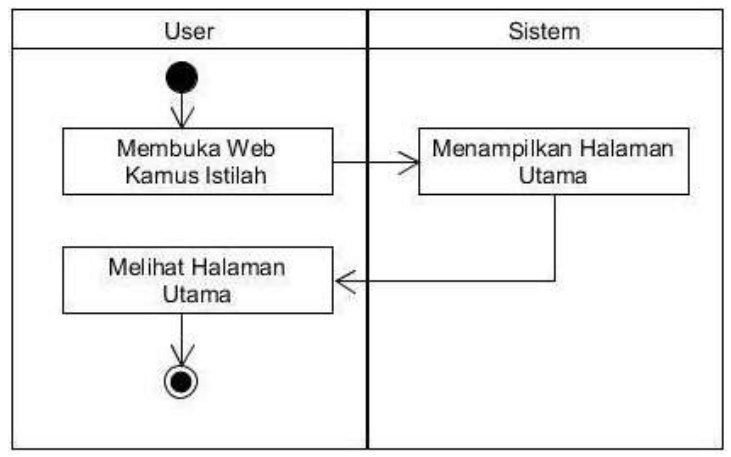

Gambar 5. Activity Diagram Halaman Utama

\subsubsection{Activity Diagram Admin}

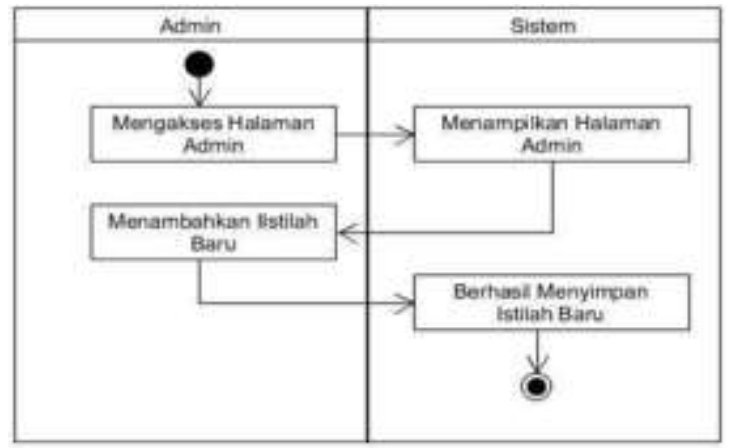

Gambar 6. Activity Diagram Admin 


\subsubsection{Activity Diagram Edit Istilah}

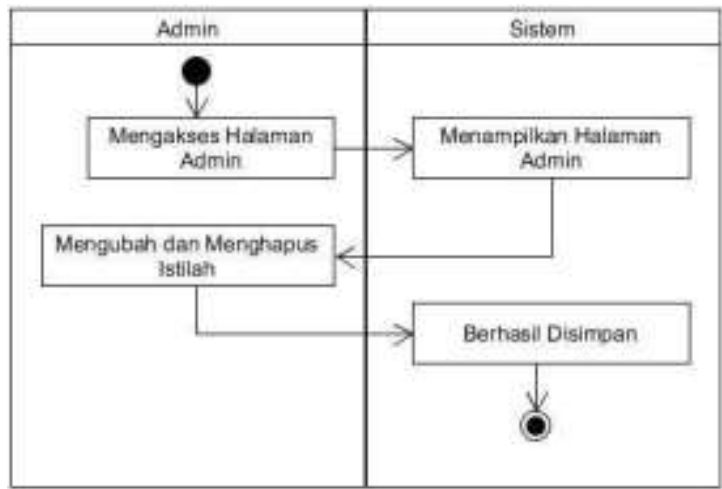

Gambar 7. Activity Diagram Edit Istilah

\subsubsection{Activity Diagram User}

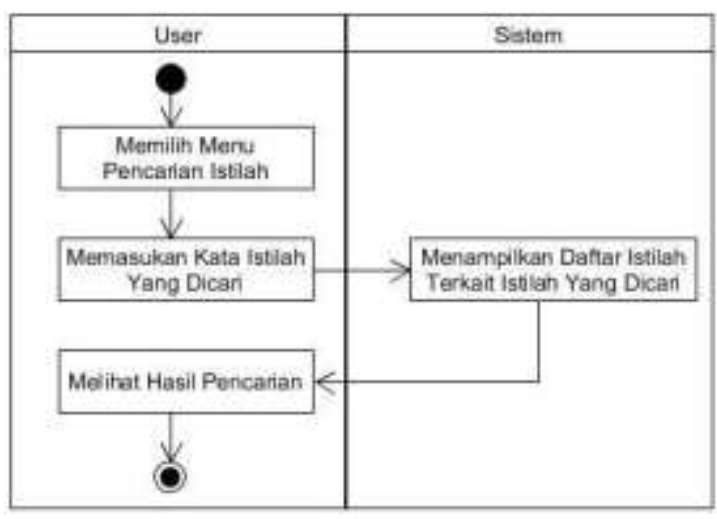

Gambar 8. Activity Diagram User

\subsubsection{Acitivity Diagram Kritik dan Saran}

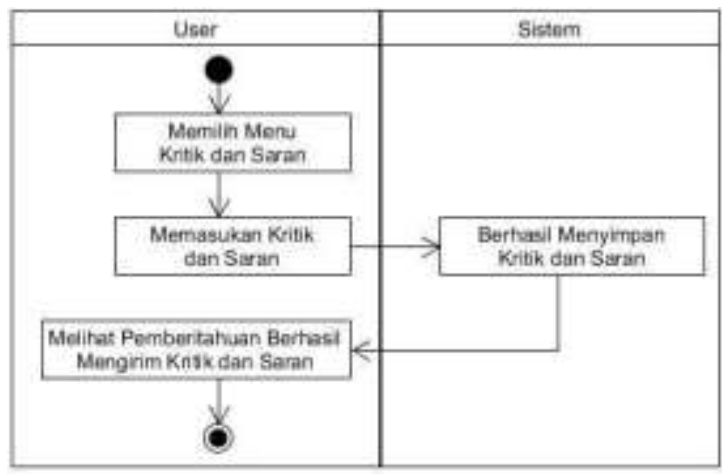

Gambar 9. Activity Diagram Kritik dan Saran

\subsection{Sequence Diagram}

Sequence diagram biasa digunakan untuk menggambarkan scenario atau rangkaian langkah-langkah yang dilakukan sebagai sebuah event untuk menghasilkan output tertentu. Gambar 10 adalah sequence diagram dari kamus istilah ilmu komputer berbasis web.

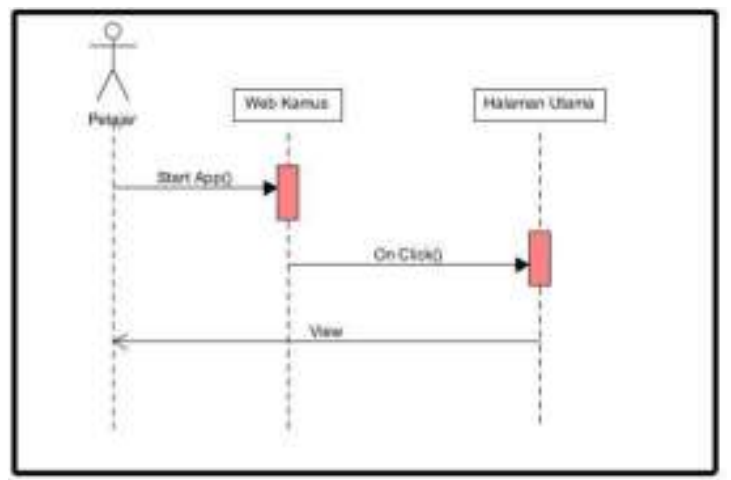

Gambar 10. Sequence Diagram Halaman Awal

\section{Hasil dan Pembahasan}

Pada Hasil dan Pembahasan ini akan dijelaskan mengenai hasil uji coba perangkat lunak perancangan Kamus Istilah Ilmu Komputer dengan Algoritma Boyer Moore Berbasis Web.

Selain itu dari hasil uji coba yang telah dilakukan akan dianalisis apakah rancangan ini dapat memenuhi tujuan yang akan dicapai.

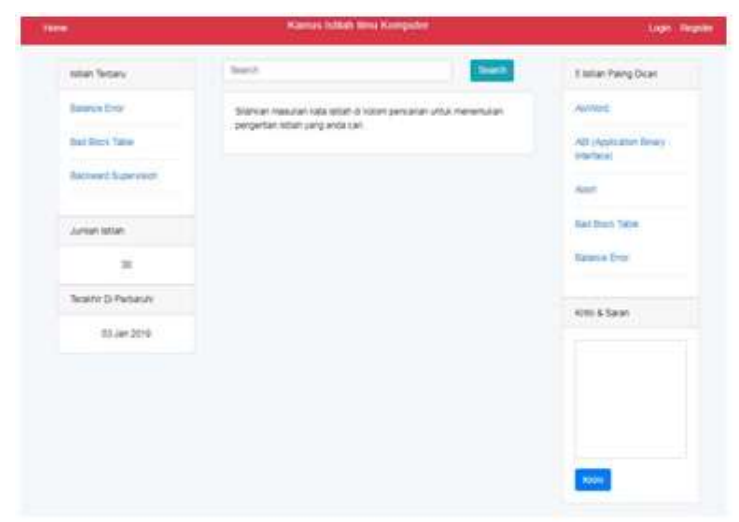

Gambar 11. Tampilan Halaman Awal 
Gambar 11. Tampilan awal saat mengakses web kamus istilah ilmu komputer.

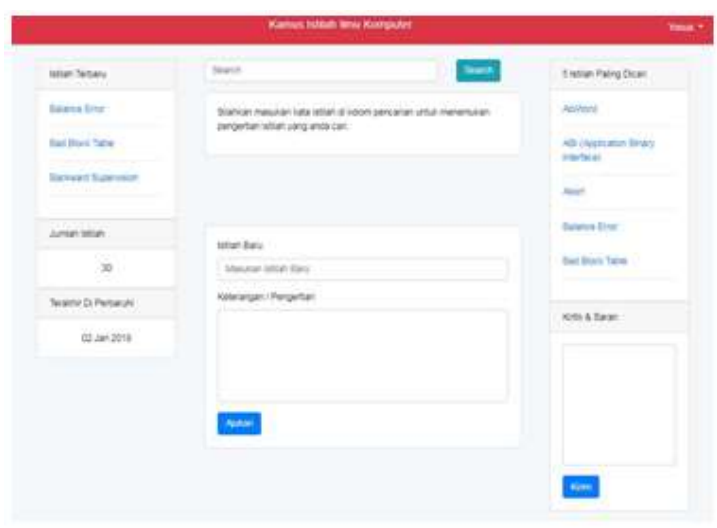

Gambar 12. Tampilan Awal Halaman User

Gambar 12. tampilan awal saat user sudah login di web kamus istilah ilmu komputer.

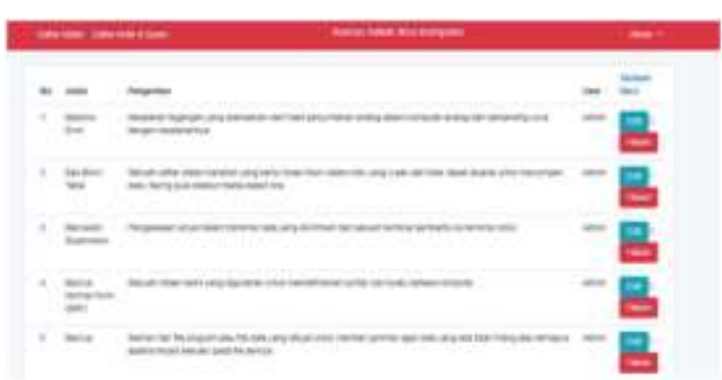

Gambar 13. Tampilan Halaman Admin

Gambar 13. adalah merupakan tampilan awal admin saat sudah login di web kamus istilah ilmu komputer. Dimana terdapat fitur untuk admin mengedit istilah yang ada dan menghapus.

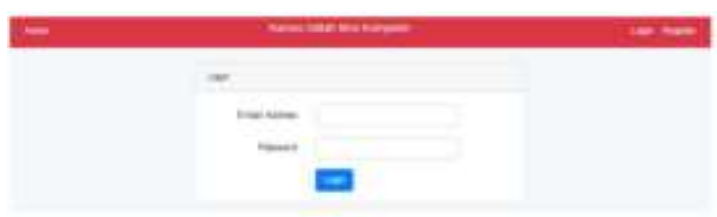

Gambar 14. Tampilan Halaman Login

Gambar 14. Tampilan dari form untuk masuk atau login ke dalam web kamus istilah ilmu komputer.

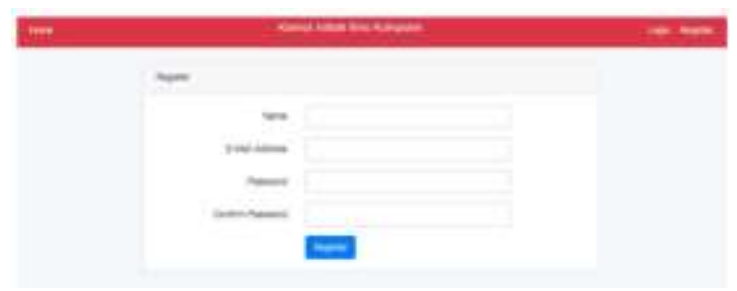

Gambar 15. Tampilan Form Data User

Gambar 15. Tampilan dari form untuk mendaftar sebagai user atau pengguna di dalam web kamus istilah ilmu komputer, agar dapat mengajukan istilah baru ke admin.

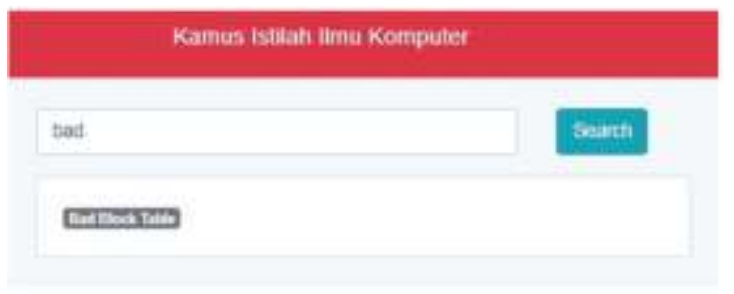

Gambar 16. Tampilan Kolom Pencarian Istilah

Gambar 16. Tampilan dari kolom pencarian yang dapat digunakan oleh pengguna untuk memasukan kata kunci istilah yang ingin dicari.

$$
\begin{aligned}
& \text { Gambar 17. Tampilan Kritik dan Saran } \\
& \text { Gambar 17. Tampilan kritik dan } \\
& \text { saran dari para penguna kamus } \\
& \text { yang hanya dapat dilihat oleh } \\
& \text { admin setelah masuk ke dalam } \\
& \text { web kamus istilah sebagai admin. }
\end{aligned}
$$




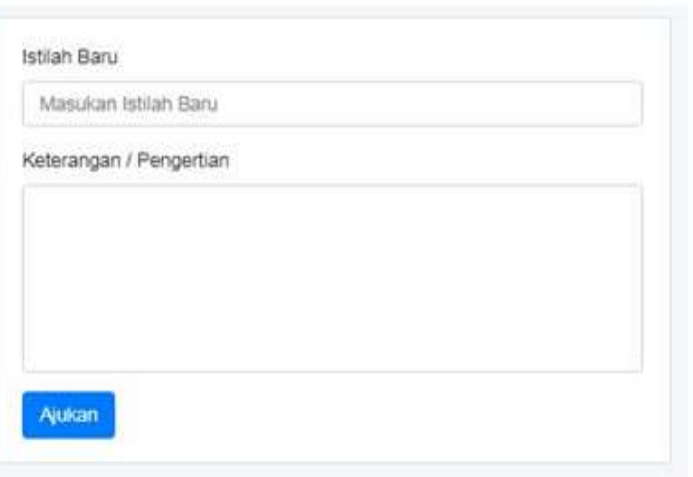

Gambar 18. Tampilan Form Pengajuan Istilah Baru

Gambar 18. Tampilan dari form pengguna yang sudah terdaftar untuk melakukan pengajuan istilah baru terhadap admin.

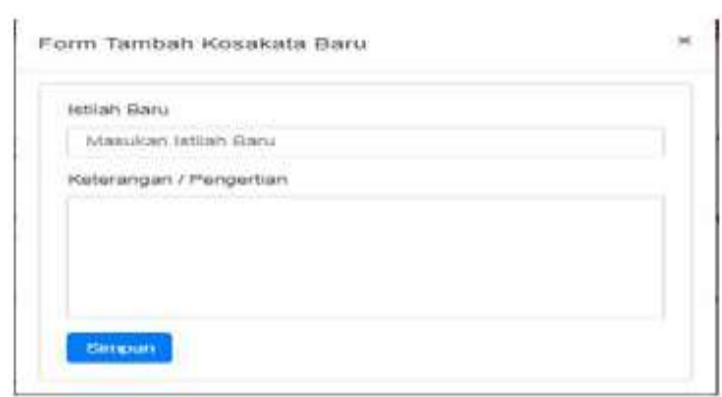

Gambar 19. Tamppilan Penambahan Istilah Baru

Gambar 19. Tampilan dari form untuk admin menambahkan langsung istilah baru ke dalam kamus

Desain Database Web
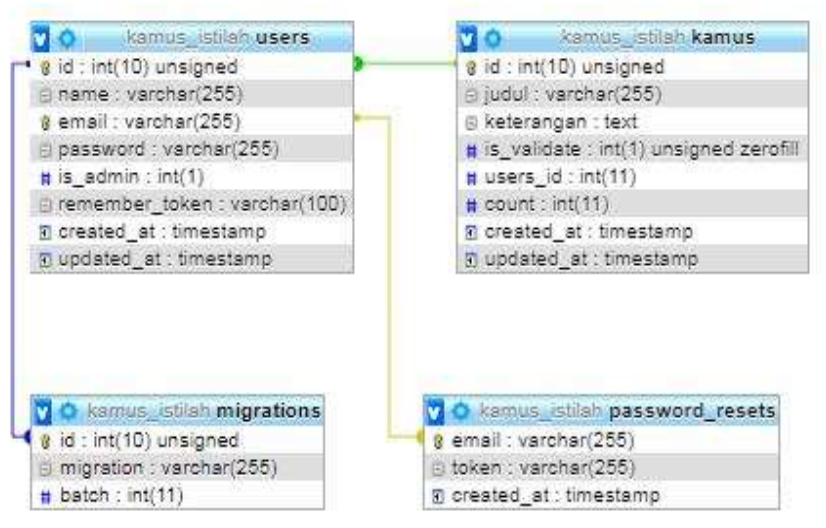

Gambar 20. Tampilan desain dari database yang ada pada web kamus istilah ilmu komputer ini.

\section{Pengujian}

Tahapan ini adalah tahapan untuk melakukan pengujian pada sistem yang diusulkan, jika semua sudah teruji maka tahapan pengembangan sistem selesai.

Tabel 2. Rencana Pengujian

\begin{tabular}{|l|l|l|}
\hline Kata Uji & Detail Pengujian & Jenis Uji \\
\hline Halaman Utama Web & $\begin{array}{l}\text { Menampilkan menu utama yang berisi } \\
\text { menu }\end{array}$ & Black box \\
\hline Register User & Menampilkan form daftar sebagai user & Black box \\
\hline Login User & Menampilkan menu login & Black box \\
\hline $\begin{array}{l}\text { Menu Tambahkan } \\
\text { Istilah }\end{array}$ & $\begin{array}{l}\text { Menampilkan form penambahan } \\
\text { istilah baru }\end{array}$ & Black box \\
\hline Menu Kritik dan Saran & Menampilkan menu kritik dan saran & Black box \\
\hline Menu Pencarian Istilah & Menampilkan kolom pencarian istilah & Black box \\
\hline
\end{tabular}

Tabel 3. Hasil Pengujian Black Box Kamus Istilah Ilmu Komputer

\begin{tabular}{|l|l|l|l|}
\hline Menu & $\begin{array}{l}\text { Skenario } \\
\text { Pengujian }\end{array}$ & $\begin{array}{l}\text { Hasil yang } \\
\text { diharapkan }\end{array}$ & $\begin{array}{l}\text { Hasil } \\
\text { Pengujian }\end{array}$ \\
\hline $\begin{array}{l}\text { Halaman Utama } \\
\text { Web }\end{array}$ & $\begin{array}{l}\text { User masuk ke } \\
\text { halaman utama } \\
\text { web kamus istilah } \\
\text { ilmu komputer }\end{array}$ & $\begin{array}{l}\text { User berhasil masuk } \\
\text { ke halaman utama } \\
\text { web kamus istilah } \\
\text { ilmu komputer }\end{array}$ & Berhasil \\
\hline Register User & $\begin{array}{l}\text { User mengisi data } \\
\text { untuk dapat login } \\
\text { ke aplikasi }\end{array}$ & $\begin{array}{l}\text { User berhasil } \\
\text { terdaftar di aplikasi } \\
\text { dan dapat login }\end{array}$ & Berhasil \\
\hline Login User & $\begin{array}{l}\text { User input } \\
\text { username dan } \\
\text { password }\end{array}$ & $\begin{array}{l}\text { User berhasil login } \\
\text { dan menampilkan } \\
\text { home user }\end{array}$ & Berhasil \\
\hline $\begin{array}{l}\text { Menu } \\
\text { Tambahkan }\end{array}$ & $\begin{array}{l}\text { User mengisi form } \\
\text { pengajuan istilah } \\
\text { baru }\end{array}$ & $\begin{array}{l}\text { User dapat berhasil } \\
\text { mengisi form } \\
\text { pengajuan istilah } \\
\text { baru }\end{array}$ & Berhasil \\
\hline $\begin{array}{l}\text { Menu Kritik } \\
\text { dan Saran }\end{array}$ & $\begin{array}{l}\text { User dapat } \\
\text { memberikan kritik } \\
\text { dan saran kepada } \\
\text { admin }\end{array}$ & $\begin{array}{l}\text { Kritik dan saran dari } \\
\text { user berhasil } \\
\text { terkirim ke admin }\end{array}$ & Berhasil \\
\hline $\begin{array}{l}\text { Mentilah Pencarian } \\
\text { User menemukan } \\
\text { istilah yang dicari }\end{array}$ & $\begin{array}{l}\text { User berhasil } \\
\text { menemukan istilah } \\
\text { yang dicari }\end{array}$ & Berhasil \\
\hline
\end{tabular}




\section{SimpUlan}

Setelah penulis melakukan penelitian dan menguraikan seluruh pembahasan mengenai kamus istilah ilmu komputer dengan algoritma boyer moore berbasis web, maka dapat disimpulkan sebagai berikut : dengan adanya kamus istilah komputer berbasis web dapat mempermudah dan membantu siswa memahami arti dari istilah - istilah dibidang komputer, selain itu dapat menjadi interaktif karena dapat menerima kritik serta saran dari pengguna secara lansung ke admin web. Dengan menggunakan kamus istilah komputer berbasis web diharapkan kedepannya dapat dikembangkan dalam bentuk platform android

\section{DAFTAR PUSTAKA}

[1] J. Hutahaean, Konsep Sistem Informasi, Yogyakarta: Deepublish, 2015.

[2] KBBI. (n.d.). Retrieved from https://kbbi.web.id/kamus.

[3] Rahmanita, E. (2014). Pencarian String Menggunakan Algoritma Boyer Moore

Pada Dokumen. Jurnal Ilmiah NERO Vol.1. No.1. hal 15-26.

[4] Rosman, Firdaus. 2013. "Rancang Bangun Sistem Informasi Perpustakaan Berbasis
Web”. Skripsi. Lampung:

Fakultas Matematika Dan

Pengetahuan Alam,Universitas

Lampung.

[5] Susanto, 2014. "Perancangan

Aplikasi Kamus Istilah Hewan dan Tumbuhan dengan

Menerapkan Algoritma Boyer-

Moore Berbasis Mobile". Jurnal Ilmiah STMIK Budidarma Medan, Vol.IV : 88-93.

[6] Tata Sutabri. 2012.Konsep

Sistem Informasi.Andi.

Yogyakarta 